\title{
THE EFFECT OF RECIPROCAL TEACHING LEARNING MODEL INTEGRATED MIND MAP AND PERSISTENCE ON STUDENT RETENTION OF KINGDOM ANIMALIA CONCEPT
}

\author{
Dwi Septiana, Mieke Miarsyah dan Ratna Komala \\ Magister Pendidikan Biologi, Fakultas MIPA, Universitas Negeri Jakarta \\ Email: dwiseptisepti@gmail.com
}

\begin{abstract}
The low score of students learning outcome on Kingdom Animalia concept indicate that there must an improvement of students retention. The aim of this study is to know the effect of reciprocal teaching learning model that integrated with mind map and persistence on students retention. The method that used in this research is quasi experiment with $2 \times 2$ factorial design. The instruments that used in this research are learning outcome test and persistence questionnaire. The subject of this study is students of X IPA 1 and 2 from SMAN 49 Jakarta totalling 72 students. Samples were taken using simple random sampling. Analysis of data used two way anova. The result showed that : 1) There is effect of reciprocal teaching learning model integrated mind map on students retention with $p<0,05, p=0,03.2)$. There is effect of persistence on students retention with $\mathrm{p}<0,05, \mathrm{p}=0,00.3)$ There is interaction between reciprocal teaching learning model integrated mind map and persistence on students retention with $\mathrm{p}<0,05, \mathrm{p}=0,031$.
\end{abstract}

\section{Keywords: mind map, persistence, reciprocal teaching, retensi}

\section{PENDAHULUAN}

Produk dari sebuah proses belajar dinyatakan dalam bentuk hasil belajar (Soemanto, 2006). Siswa yang telah memahami konsep dapat terukur melalui hasil belajar yang baik, begitu pula sebaliknya. Hasil belajar dapat dipengaruhi beberapa faktor. Salah satu yang mempengaruhinya adalah tingkat retensi atau daya ingat siswa. Penyimpanan memori (retensi) memegang peranan yang sangat penting dalam proses belajar. Peran ini merupakan inti dari perkembangan kognitif seseorang, sebab segala bentuk proses belajar individu selalu melibatkan memorinya (Desmita, 2011). Istilah retensi dalam pembelajaran berkaitan dengan materi pembelajaran yang telah dipelajari yang mampu bertahan dalam ingatan siswa. Layaknya penyimpanan memori pada komputer, jika siswa tidak dapat memanggil atau mengingat kembali file sesuai dengan namanya, maka proses pencarian informasi pun akan gagal (Rotter, 2009).

Daya ingat siswa sangat penting dalam proses belajar. Daya ingat atau retensi dapat dipengaruhi oleh beberapa faktor. Salah satu faktor yang berpengaruh untuk meningkatkan retensi siswa adalah ketekunan (Sprenger, 2011).

Ketekunan adalah salah satu dimensi dari motivasi. Ketekunan adalah keinginan siswa untuk meneruskan agar mencapai tujuan. Keinginan tersebut mengalahkan semua rintangan, kesulitan dan keputusasaan (Child Trends, 2014). Siswa yang tekun berarti siswa yang terus berusaha untuk memahami pelajaran dengan baik. Siswa yang tekun akan memiliki retensi yang baik. Oleh karena itu, siswa yang memiliki retensi yang baik akan mendapatkan hasil belajar yang baik pula (Ratnasari, 2011). 
Berdasarkan pengalaman guru Biologi di SMAN 49 Jakarta, sebagian besar hasil belajar siswa pada konsep Kingdom Animalia berada di bawah KKM. Konsep klasifikasi makhluk hidup merupakan salah satu konsep yang dianggap sulit oleh siswa (Agboghoroma dan Otivwi, 2015). Kesulitan tersebut salah satunya karena terdapat banyak istilah ilmiah yang tidak dipahami oleh siswa (Putri, 2016).

Salah satu cara yang dapat digunakan untuk mengingat materi pembelajaran lebih baik adalah melalui mencatat dan mengulanginya. Mencatat diperlukan untuk membantu siswa dalam mengingat apa yang tersimpan di dalam memorinya. Siswa akan mudah mengingat apa yang telah dituliskannya (De Porter dan Hernacki, 2015).

Umumnya, kegiatan pembelajaran yang biasa dilakukan di SMAN 49 Jakarta menggunakan model-model pembelajaran yang sesuai dengan kurikulum 2013. Sayangnya pada pembelajaran kegiatan mencatat atau meringkas tidak ada di dalam tahapan pembelajaran. Oleh karena itu, proses pembelajaran belum maksimal dalam meningkatkan retensi siswa. Di sisi lain, mencatat adalah salah satu keterampilan belajar yang penting untuk pencapaian tujuan belajar dan hasil belajar (Djamarah, 2011).

Salah satu model pembelajaran yang dapat digunakan sebagai alternatif untuk mengatasi masalah tersebut adalah dengan model pembelajaran reciprocal teaching. Reciprocal teaching adalah suatu model pembelajaran yang mengacu pada aktivitas pembelajaran yang terjadi dalam bentuk dialog antara guru dan siswa terkait segmen dari suatu bacaan. Dialog tersebut disusun dalam empat strategi, yaitu memprediksi, mengklarifikasi istilah sulit, membuat pertanyaan dan merangkum. Selama proses pembelajaran dengan model tersebut, guru dan siswa dapat bertukar peran dalam memimpin dialog, sehingga menjadikan kegiatan ini adalah suatu kegiatan pembelajaran yang menarik dan aktif (Palinscar, 1984).

Selain model reciprocal teaching, penggunaan catatan dalam bentuk mind map dapat menjadi alternatif dalam meningkatkan retensi siswa (Buzan, 2012). Mind mapping adalah sebuah teknik mencatat sebagai bentuk ekspresi dari proses berpikir yang radian (memancar) dan menunjukkan potensi alur pikiran manusia yang tak terbatas (Liu at al, 2014). Mind map mempermudah siswa dalam mengatur, menyatukan, mempertahankan dan mengingat kembali ide-ide yang dimiliki siswa (Mona dan Khalik, 2008).

Tujuan penelitian ini adalah untuk mengetahui pengaruh penggunaan model pembelajaran reciprocal teaching terintegrasi mind map terhadap retensi siswa pada konsep Kingdom Animalia, ketekunan terhadap retensi siswa pada konsep Kingdom Animalia dan interaksi antara model pembelajaran reciprocal teaching terintegrasi mind map dengan ketekunan terhadap retensi siswa pada konsep Kingdom Animalia.

\section{METODE}

Penelitian ini dilakukan di SMAN 49 Jakarta. Adapun waktu penelitian adalah pada semester ganjil tahun ajaran 2016-2017. Populasi terjangkau pada penelitian ini adalah seluruh siswa kelas X-MIA di SMAN 49 Jakarta. Populasi target pada penelitian ini adalah seluruh kelas X-MIA. Sampel dalam penelitian ini adalah siswa kelas X-MIA 1 dan 2 . Metode yang digunakan dalam penelitian ini adalah metode quasi eksperimen.

\section{HASIL DAN PEMBAHASAN}

Tabel 1. Rekapitulasi Skor Retensi Siswa pada Berbagai Kelas 


\begin{tabular}{|c|c|c|c|c|c|c|}
\hline \multirow{2}{*}{$\begin{array}{l}\text { Rentang Skor } \\
\text { Retensi }\end{array}$} & \multicolumn{6}{|c|}{ Frekuensi Relatif Siswa } \\
\hline & A1 & A2 & A1B1 & A1B2 & A2B1 & A2B2 \\
\hline $55-64$ & $17 \%$ & $11 \%$ & - & $30 \%$ & - & $50 \%$ \\
\hline $65-74$ & $17 \%$ & $22 \%$ & - & $50 \%$ & - & $40 \%$ \\
\hline $75-84$ & $17 \%$ & $31 \%$ & - & $20 \%$ & $30 \%$ & $10 \%$ \\
\hline $85-94$ & $27 \%$ & $31 \%$ & $40 \%$ & - & $70 \%$ & - \\
\hline $95-104$ & $22 \%$ & $2,7 \%$ & $60 \%$ & - & - & - \\
\hline $105-114$ & - & $2,7 \%$ & - & - & - & - \\
\hline Rerata Skor & 81,92 & 79,43 & 95,56 & 68,80 & 86,87 & 67,24 \\
\hline Skor tertinggi & 103,33 & 105,56 & 103,33 & 76,92 & 92,00 & 77,27 \\
\hline Skor Terendah & 60 & 56,56 & 91,30 & 64,00 & 77,80 & 55,56 \\
\hline \multicolumn{7}{|c|}{ Tabel 2. Hasil Perhitungan Anava Dua Arah } \\
\hline \multicolumn{5}{|c|}{ Sumber Varians } & F hitung & $F_{\text {tabe }}$ \\
\hline \multicolumn{5}{|c|}{ Model Pembelajaran } & $10,05^{* *}$ & 4,10 \\
\hline \multicolumn{5}{|l|}{ Ketekunan } & $160,29 * *$ & 4,10 \\
\hline \multicolumn{5}{|c|}{$\begin{array}{l}\text { Interaksi antara Model Pembelajaran Recirocal Teaching terintegrasi Mind } \\
\text { Map dan Ketekunan }\end{array}$} & $5,04 *$ & 4,10 \\
\hline
\end{tabular}

Keterangan : *signifikan pada $\alpha=5 \%$

$* *$ signifikan pada $\alpha=1 \%$

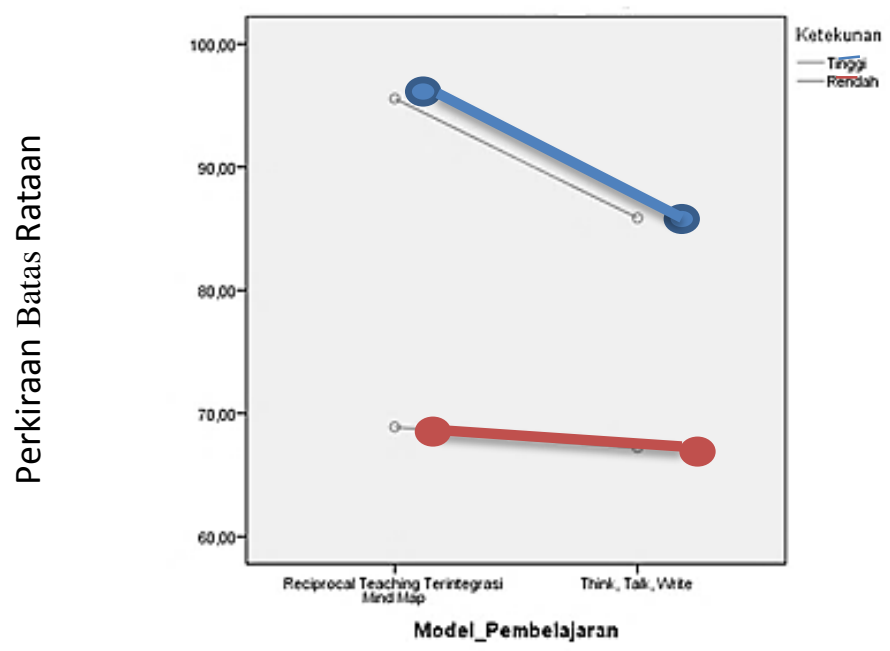

Gambar 1. Interaksi antara model pembelajaran dan ketekunan

Proses pembelajaran dengan model pembelajaran reciprocal teaching terintegrasi mind map adalah pembelajaran aktif yang terdiri dari empat strategi utama dalam memahami bacaan. Keempat strategi tersebut antara lain memprediksi, mengklarifikasi, menanya dan mencatat. Terlaksananya kegiatan pembelajaran sesuai dengan sintak memungkinkan terbentuknya pemahaman yang baik yang akan berdampak pada retensi siswa. Pemahaman yang baik akan mengurangi lupa karena materi tersebut akan tertanam dalam memori jangka panjang siswa (Anderson, 2001). Begitu pula dengan pendapat Klemm (2007) dalam penelitiannya mengenai pentingnya kemampuan mengingat dalam belajar yang menyatakan bahwa siswa akan mengingat materi pelajaran yang sudah dipahaminya. 
Berdasarkan uji hipotesis pada Tabel 1, penggunaan model pembelajaran pembelajaran reciprocal teaching terintegrasi mind map berpengaruh terhadap retensi siswa. Hal ini ditunjukkan dengan $F_{\text {hitung }}>F_{\text {tabel }}(10,05>4,10)$. Ketekunan siswa juga memiliki pengaruh terhadap retensi siswa. Hal ini ditunjukkan dengan $F_{\text {hitung }}>\mathrm{F}$ tabel $(160,29>4,10)$. Selain itu, terdapat interaksi antara model pembelajaran reciprocal teaching terintegrasi mind map dan ketekunan terhadap retensi siswa yang ditunjukkan dengan $\mathrm{F}_{\text {hitung }}>\mathrm{F}_{\text {tabel }}(5,04>4,10)$.

Kegiatan belajar yang aktif memungkinkan untuk dapat meningkatkan retensi siswa. Hal ini juga dinyatakan oleh Todd dan Tracey (2016) dalam penelitiannya mengenai pemahaman konsep dalam reciprocal teaching yang menyatakan bahwa semakin banyak siswa terlibat dalam kegiatan pembelajaran, semakin banyak pula informasi yang dapat diingatnya. Selain itu, Park (2003) juga menyatakan bahwa siswa yang terlibat dalam kegiatan pembelajaran akan membuatnya memiliki peningkatan dalam pemahaman dan retensi.

Salah satu tahapan dari model pembelajaran reciprocal teaching terintegrasi mind map adalah mencatat. Dalam penelitian ini kegiatan mencatat diintegrasikan dalam bentuk mind map. Kegiatan mencatat dalam bentuk mind map ini juga membangun suasana belajar yang lebih hidup, bersemangat dan membuat siswa memiliki perhatian atau atensi yang lebih terhadap pelajaran. Menurut Santorck pada (2009) menyatakan bahwa adanya atensi/perhatian yang lebih dari siswa terhadap pelajaran menyebabkan siswa lebih mudah mengingat informasi yang telah dimilkinya. Pendapat tersebut juga didukung oleh hasil penelitian selanjutnya yang dilakukan oleh Malahayati (2016) mengenai pengaruh pembelajaran think, pair, share terhadap hasil belajar dan retensi siswa yang menyatakan bahwa suasana pembelajaran yang meningkatakan atensi juga berpeluang meningkatakan retensi siswa.

Penggunaan teknik mencatat mind map pada penelitian ini memungkinkan siswa untuk memperoleh pengalaman belajar yang belum biasa siswa lakukan dalam belajar. Siswa dapat menyusun ide-ide melalui tampilan yang lebih menarik dari catatan konvensional. Mind map juga mempermudah siswa dalam mengatur, menyatukan, mempertahankan dan mengingat kembali ide-ide yang dimiliki siswa. Mona dan Khalik (2008) dalam hasil penelitiannya mengenai mind map dan pencapaian belajar menyatakan bahwa kreasi penggunaan warna dalam pembuatannya juga memiliki makna tersendiri bagi pembuatnya sehingga memudahkan pembuat untuk mengingatnya. Pendapat tersebut juga didukung oleh pernyataan Long dan Carlson (2011) yang menyatakan bahwa mind map adalah kreasi dan representasi visual dari pikiran pembuatnya, oleh karena itu memungkinkan pembuat mind map memiliki retensi yang lebih baik.

Berdasarkan penjelasan sebelumnya, maka penggunaan model pembelajaran reciprocal teaching terintegrasi mind map dapat meningkatkan retensi siswa. Hal ini sejalan dengan hasil penelitian Todd dan Tracey (2006) dan Muliyana (2016) bahwa penggunaan model pembelajaran reciprocal teaching mampu meningkatkan retensi siswa. Pada penelitian lain yang dilakukan oleh Pilonieta dan Medina (2009) mengenai reciprocal teaching menunjukkan bahwa penggunaan model pembelajaran ini memberikan hasil retensi yang baik setelah dilakukan retest enam bulan setelah kegiatan pembelajaran.

Selain penggunaan model pembelajaran, peningkatan retensi siswa yang terjadi juga dipengaruhi oleh faktor internal. Salah satu faktor yang terdapat pada diri siswa diantaranya adalah ketekunan. Ketekunan adalah salah satu dimensi dari motivasi. 
Siswa yang tekun berarti memiliki motivasi yang tinggi. Ketika motivasi belajar siswa tinggi, maka siswa akan menaruh atensi pada pembelajaran sehingga akan lebih mudah untuk memahami pelajaran. Hal ini sejalan dengan hasil penelitian Tella (2007) mengenai motivasi dan pencapaian dalam belajar bahwa ketekunan dalam belajar mempengaruhi pencapaian siswa dalam belajar.

Siswa yang tekun akan memiliki retensi yang baik sebab siswa yang tekun akan dengan sadar selalu berusaha mencapai apa yang ia harapkan. Keadaan demikian sejalan dengan hasil penelitian Wu, Huberman dan Alto (2009) yang menyatakan bahwa siswa yang tekun akan dengan sendirinya meningkatkan kualitas dari pencapaiannya dan kemungkinan keberhasilan meskipun menghadapi banyak rintangan. .

Ketekunan akan membantu siswa mendapatkan hasil belajar yang baik. Seseorang yang memiliki hasil belajar yang baik akan memiliki retensi yang baik, sebab tidak mungkin siswa dapat mendapatkan hasil belajar yang baik tanpa adanya proses mengingat yang baik. Hal ini didukung oleh pernyataan Sugiyanto dan Priyono (2013) bahwa hasil belajar yang baik dapat dicapai jika siswa memiliki retensi yang baik. Oleh karena itu, ada kaitan antara ketekunan, retensi dan hasil belajar.

Siswa yang tekun akan berorientasi pada prestasi, sehingga kesulitan apapun yang ditemuinya akan dapat terlewati karena kegigihan usahanya. Dalam usahanya tersebut siswa juga menaruh fokus meskipun menemui kesulitan, sehingga tugas yang diberikan kepadanya dapat diselesaikan. Oleh karena itu, siswa yang tekun akan mendapatkan pencapaian yang baik. Hal ini sejalan dengan hasil penelitian Eze (2015) yang menyatakan bahwa ketekunan memiliki hubungan positif terhadap pencapaian belajar matematik siswa.

Berdasarkan Gambar 1, interaksi yang terjadi antara penggunaan model pembelajaran pembelajaran reciprocal teaching terintegrasi mind map dan ketekunan terhadap retensi siswa ditunjukkan melalui dua garis lurus yang memiliki kemiringan yang berbeda. Kedua titik pada masing-masing garis menunjukkan bahwa kedua garis tersebut dapat diperpanjang sesuai banyaknya data. Kedua garis pada gambar tersebut tidak saling berpotongan namun keduanya terlihat saling mendekat. Hal ini menunjukkan adanya interaksi antara keduanya. Hal ini didukung oleh pernyataan Laratu, Darsikin dan Wahyono (2016) bahwa meskipun tidak saling berpotongan, kedua garis pada grafik anava dua jalur yang saling mendekat menunjukkan adanya interaksi diantara kedua variabel penelitian. Adapun penyebab tidak berpotongannya kedua garis tersebut adalah adanya faktor-faktor lain yang mempengaruhi interaksi tersebut yang tidak diteliti dalam penelitian ini. Oleh karena itu, diharapkan pada penelitian selanjutnya dapat diketahui faktor-faktor yang mempengaruhi interaksi keduanya. Namun pendapat ini tidak sejalan dengan Santoso (2010) yang menyebutkan bahwa jika pola garis pada grafik anava dua jalur tidak saling berpotongan, maka hal tersebut menunjukkan bahwa tidak terdapat interaksi. Hal senada juga dinyatakan oleh Field (2009) yang menjelaskan bahwa tidak adanya perpotongan garis pada grafik anava dua jalur menunjukkan tidak ada interaksi diantara kedua variabel.

Penggunaan model pembelajaran reciprocal teaching terintegrasi mind map merupakan model pembelajaran aktif yang dapat meningkatkan retensi. Dalam model pembelajaran tersebut tahapan mencatat diwujudkan dalam bentuk membuat mind map. Mind map yang dibuat terdiri dari asosiasi kata-kata dan gambar visual. Di sisi lain, ketekunan juga merupakan suatu sikap yang penting dimiliki oleh setiap siswa. Seperti pada pembahasan sebelumnya, bahwa ketekunan akan membawa siswa untuk dapat memiliki retensi dan hasil yang terbaik dalam belajar. 
Hasil penelitan yang menunjukkan tingginya nilai retensi pada kelompok siswa yang belajar dengan model pembelajaran reciprocal teaching terintegrasi mind map menunjukkan pentingnya guru untuk mampu mendesain pembelajaran yang aktif dan menarik bagi siswa. Selain itu, bagi siswa yang belum tekun dapat didukung untuk meningkatkan ketekunan dengan berbagai cara, baik dukungan dari diri siswa (meningkatkan kesadaran pribadi) maupun lingkungan belajarnya (proses belajar yang ada di kelas). Adanya interaksi antara desain pembelajaran yang baik dari guru dan ketekunan yang ada pada diri siswa akan membantu siswa mencapai retensi yang optimal. Apabila retensi siswa telah baik, maka hasil belajar siswa pun akan baik.

\section{KESIMPULAN}

Berdasarkan hasil penelitian, penggunaan model pembelajaran reciprocal teaching terintegrasi mind map berpengaruh terhadap retensi siswa. Selain itu, ketekunan juga memiliki pengaruh terhadap retensi siswa. Adanya interaksi model pembelajaran reciprocal teaching terintegrasi mind map dan ketekunan juga berpengaruh terhadap retensi siswa.

\section{DAFTAR PUSTAKA}

Agboghoroma, T \& Oyovwi, E.O. (2015). Evaluating Effect of Student's Academic Achievement Identified Difficult Concepts in Senior Secondary School Biology in Delta State. Journal of Education and Practise. 6: 30: 117-125.

Anderson, L. W. \& Krathwohl D. R. (2001). Learning, Teaching, and Assessing. New York: Addison Wesley Longman, Inc.

Buzan, T. 2012. Buku Pintar Mind Map. Jakarta : Gramedia.

Child Trends. (2014). Measuring Elementary School Student's Social and Emotional Skills. Child Trends Publication.

De Porter, B, \& Hernacki, M. (2015). Quantum Learning: Membiasakan Belajar Nyaman dan Menyenangkan. Bandung : Kaifa.

Desmita. (2011). Psikologi Pendidikan. Bandung: Remaja Rosdakarya.

Djamarah, S.B. (2011). Psikologi Belajar. Jakarta: Rineka Cipta.

Eze, M.S. (2015). Relationship Among Mathematics Teachers' Self-Efficacy Belief, Methematics Students's Persistence and Achievement in Nsukka Education Zone of Enugu State. Thesis of University of Nigeria.

Huberman, B, \& Wu, F. (2009). A Persistence Paradox. Research Report.

Klemm, W. R. (2007). What Good is Learning if You Don't Remember it?. Journal of Effective Teaching. 7: 1: 61-73.

Laratu, W, Darsikin, \& Wahyono, U. (2016). Pengaruh Model Pembelajaran Kooperatif Tipe STAD Berbasis Media Animasi dan Kemampuan Awal terhadap Pemahaman Konsep Listrik Dinamis Siswa SMA Negeri 8 Palu. E-Jurnal Mitra Sains. 4: 2: 78-85. 
Liu, Y, Zhao, G, \& Bo,Y. (2014). The Effect of Mind Mapping in Teaching and Learning: A Meta Analysis. Standard Journal of Educational and Essay. 2: 1: 17-31.

Long, D \& Carlson, D. (2011). Mind the Map: How Thinking Maps Affect Student Achievement. An Online Journal for Teacher Research. 13: $2: 1-7$.

Malahayati. 2016. Pembelajaran Berbasis Masalah Melalui Think Pair Share Terhadap Hasil Belajar Biologi dan Retensi Siswa. Jurnal Konstruktivisme. 8: 2: 131-147.

Mona, I.A.E \& Khalick, F.A.E. (2008). The Influence of Mind Mapping on Eight Graders's Science Achievement. School Science and Mathematics Journal. 108: $7: 298-313$.

Muliyana, R \& Djumadi. (2016). Pengaruh Strategi Pembelajaran Reciprocal Learning dan Think Talk Write terhadap Hasil Belajar dan Retensi Siswa pada Mata Pelajaran IPA Biologi Kelas VIII SMP Negeri 1 Sambi Tahun Pelajaran 2015/2016. Proceeding Biology Education Conference. 13: 1: 488-492.

Palincsar, A.S \& Brown, A.L. (1984). Reciprocal Teaching of Comprehension Fostering and Comprehension Monitoring Activities. Journal of Cognition and Instoruction in Michigan State University. 1: 2: 117-175.

Pilonieta \& Medina. (2009). Reciprocal Teaching for the Primary Grades : "We Can Do It, Too!'.International Reading Association Journal. 63: 2 : 120-129.

Putri, L.O.L. (2016). Kartu Identifikasi Filum Sebagai Media Pembelajaran Yang Inovatif Untuk Mempelajari Materi Klasifikasi Hewan. Jurnal Pendidikan Biologi Indonesia. 2: 1: 31-38.

Ratnasari, Y. (2011). Penerapan Strategi SQ3R dan Peta Konsep Dalam Pembelajaran Fisika Ditinjau dari Kemampuan Memori Siswa. Jurnal Refleksi Edukatika. 1: 2: 126-134.

Rotter, K. M. (2009). Enhancing Memory in Your Students: Compose Yourself. Teaching Exceptional Children Plus Journal. 5: 3: 1-16.

Santrock. (2009). Psikologi Pendidikan. Jakarta: Kencana Prenada Media Group

Soemanto, W. (2006). Psikologi Pendidikan. Jakarta: Rineka Cipta.

Sprenger, M. (2011). How to Teach so Students Remember. Jakarta: Erlangga.

Sugiyanto \& Priyono. (2013). Pengaruh Metode Pembelajaran Pemecahan Masalah, Retensi Belajar, dan Motivasi Belajar Terhadap Hasil Belajar Siswa SMK. Jurnal Teknologi dan Kejuruan. 36: $1: 19-28$.

Tella, A. (2007). The Impact of Motivation on Student's Academic Achievement and Learning Outcomes in Mathematics among Secondary School Students in Nigeria. Eurasia Journal of Mathematics, Science \& Technology Education. 3: 2: $149-156$.

Todd, R \& Tracey, D. (2006). Reciprocal Teaching and Comprehension. A Single Subject Research Study in Reading Specialization. Kean University. 